\title{
Spelling Characteristics of Early Grade Elementary School Children with Language Learning Disabilities
}

\author{
Song-I Han, Kyung Hee Jung \\ Department of Speech and Language Pathology, Graduate School of Rehabilitation and Welfare, Yongin University, Yongin, Korea
}

Correspondence: Kyung Hee Jung, PhD Department of Speech Language Rehabilitation, Yongin University, 134 Yongindaehak-ro, Cheoingu, Yongin 17092, Korea

Tel: $+82-31-8020-2864$

Fax: +82-31-8020-3075

E-mail: 1012jkh@hanmail.net

Received: April 5, 2018

Revised: May 28, 2018

Accepted: June 8, 2018

This work is based on a part of the first author's master's thesis from Yongin University.

\begin{abstract}
Objectives: The purpose of this study is to identify differences in spelling performances between children with language-learning disabilities and typical developing children from first grade to third grade in elementary school, compared in parallel, by spelling rules and phonological rules. Methods: A total of 20 students from 1st to 3 rd grade participated in this study. Research tools were composed of four different types of assignments based on different spelling types, which were dictation based assessments selected upon four different phonological rules. Results: First, there were significant differences between children with language-learning disabilities and typical developing children by spelling type. Also, there were significant interactions between groups and spelling type. Second, significant differences were observed between children with language-learning disabilities and typical developing children by phonological rules. There were no interaction effects between groups and spelling type. Third, children with language-learning disabilities made more errors than typical developing children in phonological processing and orthographic processing, whereas the difference between the two groups in morphological processing errors was no significant. Conclusion: The difference in spelling performance by spelling type and phonological rules suggest that we must take spelling types and phonological rules into account when teaching spelling skills to children with language-learning disabilities. In particular, differences in the number of morphemes observed in spelling performances imply that we must consider incorporating morpheme developing disciplines when teaching in spelling skills.
\end{abstract}

Keywords: School-aged children, Language learning disabilities, Spelling, Spelling type, Phonological rules
읽기와 쓰기는 의사소통의 한 방법으로 현대사회를 살아가는 데 중요한 요소이며, 특히 학령기에는 읽기, 쓰기의 중요성이 더 부 각된다. 일반아동은 초등 저학년 동안 읽기의 기본 기능을 대부분 습득하며, 학습활동을 중심으로 한 쓰기기술을 익히게 된다. 고학 년 이후에는 고급 독해기술이 중요하게 다루어지며, 저학년 때 습 득된 쓰기기술이 다양한 교과목으로 확장되어 적용되면서 학습이 이루어진다 $(\mathrm{Ga}, 2006 ; \mathrm{Heo}, \mathrm{Kwak}, \&$ Lee, 2011). 이처럼 읽기와 쓰 기는 저학년부터 고학년에 이르기까지 모든 학습에 기본이 되며 학업성취 및 학교생활의 성패와도 직결되는 중요한 기능이라 할 수 있다(Kwon, 2004).

또한 쓰기는 철자, 구문, 의미, 관습적인 규칙 등에만 한정된 것이
아니며, 다양한 언어적 능력과 철자법, 그리고 근육운동 등이 필요 한 복잡한 과정으로 이루어져 있으며, 대부분의 아동들은 읽기보 다 쓰기에서 더 어려움을 느낀다. 쓰기의 발달은 일반적으로 초기 쓰기형태가 나타나는 2-3세경부터 시작하며, 학령기를 거쳐 점차 발달해 나가게 된다. 즉, 학령초기에는 다양한 쓰기 경험을 하게 되 고 전사하기와 같은 기술에 초점을 두지만 학령기 중. 후기 아동의 쓰기는 학습의 도구로 기능하게 된다. 즉, 이야기글, 설명글, 설득글 과 같은 지식전달의 양식에 따라 어휘 및 문장형식이 달라지는 학 습 기술을 습득하게 된다(Scott, 2005). 성공적인 학교생활을 위해 중요한 능력인 쓰기에 대해 Kim (2013)은 쓰기를 철자능력과 작문 능력으로 나누어 초등학생 1-5학년을 대상으로 한 쓰기능력에 대 
한 예측변인을 살펴본 결과 어휘, 표기인식, 형태인식, 자음소리, 단 어인지는 철자능력과 관련된 예측변인에 포함되며, 어휘, 형태인식, 작동기억, 듣기이해, 읽기이해, 철자는 작문능력의 예측변인으로 나타났다. Jo, Kim과 Jeong (2006)은 음운인식과 단어읽기가 유아 의 쓰기능력과 유의한 상관이 있으며, 무의미 단어읽기, 음소인식 순으로 쓰기능력 점수를 예측해준다고 보고하였다.

또한 철자쓰기에 영향을 미치는 주요 변인으로 철자지식과 자 소-음소 대응규칙에 대한 지식을 들 수 있는데, 이 중 철자인식 혹 은 철자지식(orthographic knowledge)은 우리 기억 속에 저장된 구 어를 문어의 형식으로 표현하는 패턴이나 방법에 대한 정보를 의미 한다(Apel, 2011). Chung (2015)은 철자지식이 뚜렷하게 발달한 아 동은 철자에 의식적으로 주의를 기울이지 않아도 좀 더 복잡한 문 장이나 작문에 몰입할 수 있다고 하였으며, 불완전하게 형성된 철 자의 표상을 수정하거나 더 정확하게 쓰기 위해서는 음운, 형태 그 리고 철자패턴에 관한 지식이 형성되어야 한다고 하였다.

이 중 영어권 연구에서는 철자쓰기 발달을 일반적으로 소리 또 는 음운처리 단계, 패턴 또는 표기처리 단계, 의미 또는 형태처리 단 계로 나누어 설명하고 있다(Henderson, 1990). 음운처리 단계에서 아동은 단어의 소리와 글자 또는 낱자를 연결시켜 철자하고, 패턴 또는 표기처리 단계에서는 모든 단어가 자소-음소 대응관계를 통 해 철자되지 않음을 인식하고 위치에 따라 철자되는 원리를 적용하 고 이해하게 된다. 마지막으로 의미 또는 형태처리 단계에서는 의미 를 지닌 단어부분은 발음이 바뀌어도 철자는 변하지 않는다는 것 을 인식하고 적용한다(Adams, 1990; Henderson, 1990). 반면 우리 나라 연구에서 $\operatorname{Kim}$ (2009)은 한글이 자소-음소 일대일 대응을 원 칙으로 하지만, 하나의 뜻을 나타내는 글자의 형태가 단어 내에서 위치에 따라 다르게 발음되는 경우가 많은 것이 특징이라고 하였 다. 이로써 외국의 선행연구에서 제시한 철자발달 단계가 한글에 서도 비슷한 패턴을 보인다는 것을 알 수 있다. 그러나 한글의 경우 에는 음운규칙이 적용되는 단어가 상당히 많기 때문에 음운규칙 별 발달패턴을 포함해서 살펴볼 필요가 있다. Yang (2014)은 초등 학교 저학년을 대상으로 철자발달 특성을 연구한 결과 철자유형 중 음운유형은 대부분 1 학년 때 학습이 완성되고 기본 종성 등 어 려운 음운유형은 3 학년에 완성되나, 형태유형에서는 대부분 3 학년 까지도 완전하게 습득되지 않았다고 보고하였다. 이는 음운유형이 형태유형보다 먼저 발달함을 보여주었다. 또한 만 5세 일반아동을 대상으로 한 추적연구에서는 자소-음소 대응이 명백한 기본 초성, 기본 종성, 기본 모음의 음운학적 유형들이 먼저 습득되고 어려운 음운규칙이나 7종성 패턴 등은 나중에 습득된다고 하였다(Yang, 2009). 하지만 한글의 경우, 받침 소리가 7개 자음으로만 발음되는
칠종성 법칙과 단어 내에서의 위치에 따라 소리가 바뀌는 음운규 칙이 적용되는 단어가 많기 때문에 영어권에서 나타난 음운처리, 표기처리, 형태처리의 기준뿐 아니라, 음운규칙별 발달패턴도 함께 살펴볼 필요가 있다(Kim, 2009).

철자발달이 진행됨에 따라 보다 성숙한 문자사용을 위해 다양 한 철자전략들을 사용하게 되는데(Bear, Invernizzi, Templeton, \& Johnston, 2016), 철자전략은 음운전략, 표기전략, 형태전략으로 나 누어진다. 음운전략은 자소-음소에 대한 지식을 알고 소리 나는 대 로 표기하는 전략이며, 표기전략은 문자 안에서 익숙하게 나타나 는 자소의 패턴을 활용하는 전략이다. 마지막으로 형태전략은 형 태소에 대한 지식을 철자에 사용하는 전략이다. Frith (1985), Henderson (1990)은 철자발달 시작은 음운지식 즉음운전략을 사용하 다가 약 만 7,8세가 되면 진정한 의미에서 형태소를 지켜 쓰려는 모 습을 보인다고 하였다. 하지만 Treiman과 Cassar (1996)는 어린 학 생들이 형태소에 대한 지식을 활용하여 철자하는지 관찰한 결과, 아동들이 단일형태소를 철자할 때는 두 개의 연속되는 자음 중 첫 자음을 생략하는 모습을 보이고(예: BRAD for brand), 어간에 문 법형태소가 붙어있는 단어에서는 어간을 살리기 위해 첫 자음을 표기하였다(예: RAND for rained)고 보고하였다. 이는 만 5세 학령 전기 아동들도 형태전략을 사용하고 있음을 보여준다. 우리나라의 Yang (2009) 연구에서도 만 5세 아동들은 경음화 되는 단어나 7종 성 패턴 등과 같은 형태소적 지식이 필요한 철자 유형을 정확하게 철자하기 시작한다는 것을 보여주었으며, 어린 학생들도 형태소를 철자하게 되는 이유를 형태소에 대한 노출빈도가 높아지면 어린 학 생들도 형태소에 대한 지식과 전략을 철자에 반영할 수가 있다고 하였다. 즉, 철자전략에 대한 연구대상이 고학년일 경우에는 대부 분 형태전략 사용에 유의미한 차이를 보였으나, 저학년일 경우에는 일정한차이를 보이지 않았다.

또한 최근 철자쓰기에 어려움을 보이는 집단에 대한 연구가 이루 어져 왔는데 대부분 철자부진 아동, 읽기장애 아동, 청각장애 아동, $\mathrm{ADHD}$ 아동 등을 대상으로 연구되어왔다. $\operatorname{Kim}$ (2012)은 인공와우 이식 아동과 일반아동을 대상으로 철자쓰기 검사를 실시한 결과 인공와우이식 아동이 일반아동에 비해 철자쓰기 총점 평균이 낮 은 것으로 나타났으며, 3-4학년 $\mathrm{ADHD}$ 아동과 일반아동을 대상으 로 Ko (2014)의 연구에서도 $\mathrm{ADHD}$ 아동들이 일반아동에 비해 유 의하게 높은 오류율을 보였다. 이는 일반아동에 비해 철자쓰기에 어려움이 있다는 것을 보여준다. Kim (2009)은 1-6학년 철자부진 아동을 대상으로 철자발달 패턴과 오류유형을 분석한 결과, 1-3학 년의 경우 철자부진 아동은 일반아동들과 유의한 철자발달 패턴 을 보였으며, 초등학교 3학년 이후에는 다소 완만한 발달 패턴을 보 
였다. 또한 Kim, Choi와 Kim (2010)은 철자부진 아동이 자소-음소 의 대응이 불규칙한 단어의 철자 수행력이 상당히 낮았으며, 이는 아동이 글자와 소리의 대응규칙은 알고 있으나 한글맞춤법에 따른 철자법을 적용하지 못한 것이라고 하였다. Choi, Kim, Yun과 Sung (2011)은 읽기장애 아동이 친숙도가 낮은 낱말과 음운규칙이 적용 되는 낱말의 받침철자에 대해 이해력이 부족하며, 특히 겹받침 철 자에서 어려움을 보인다고 하였다. 또한 초등학교 3학년 읽기 장애 아동을 대상으로 읽은 후 다시 말하기와 다시 쓰기라는 읽기전략 을 비교한 Jung과 Kim (2012)의 연구결과 읽기장애 아동은 쓰기보 다 다시 말하기가 읽기이해에 더 효과적이라고 하였다. 이는 읽기장 애 아동이말하기보다쓰기에 더 어려움을 보인다는 것을 알수 있다.

언어학습장애란 읽기학습에 어려움이 있는 아동의 하위 유형으 로 구어에서의 결함이 두드러지는 언어학적 기초능력과 관련된 읽 기 및 쓰기에 어려움이 있는 아동이다(Butler \& Silliman, 2002). 언 어학습장애 아동은 음운, 구문, 의미, 화용 등 언어학적 측면에서 의 어려움이 있으며, 이러한 부족한 언어기술로 읽기학습에 노출됨 에 따라 읽기결함이 동반되어 나타나는 경우가 많다(Owens, 2012). 또한 언어학습장애 아동의 언어적 문제는 글을 읽고 이해하는 데 어려움뿐 아니라 쓰기 및 철자 사용에서 부족을 야기할 수 있다 (Kim, 2016). 언어학습장애 아동은 말 산출에서 명백한 오류를 반 드시 갖지는 않으나, 어려운 단어나 구 또는 복잡한 비단어 등의 복 잡한 음운산출에서 종종 장애를 보인다(Pennington \& Bishop, 2009). 또한 음운산출에 이상이 없을 경우에도 음운처리의 '기저' 결함을 지속적으로 가지고 있으며, 이러한 결함은 읽기학습에 중요 한 영향을 끼친다(Liberman \& Liberman, 1990). Scott (2004)은 언 어학습장애 아동이 보통 자발어에서는 많은 실수를 범하지 않으나 쓰기에서는 많은 실수를 범한다고 하였다.

아동들은 철자발달 과정에서 철자전략을 사용하게 되는데, 최 근 몇몇 외국연구들에서는 쓰기능력에 영향을 미치는 변인으로 철 자전략에 대해 탐색해 오고 있다. Sangster와 Deacon (2011)은 철자 를 1 형태소와 2 형태소로 나누어 형태전략의 사용을 살펴보았으며, Deacon과 Bryant (2005)의 연구에서도 철자검사를 1형태소와 2형 태소로 나누었으며, 2형태소는 다시 접사가 포함된 굴절어와 파생 어로 나누어 살펴보았다. 이는 아동이 형태소 분절방법을 알고 있 을 경우 2 형태소 단어를 정확하게 기술할 수 있음을 의미하며, 이것 을 통해 아동의 형태전략 사용능력을 살펴보았다. 하지만 국내연구 에서는 아직 형태전략에 대해 자세히 살펴보지 못했는데 형태소지 식이 읽기에 영향을 미친다는 연구는 보고되고 있다(Jung, 2014; Kim, \& Jung, 2015a, 2015b). 우리나라에서도 외국의 선행연구에서 처럼 형태소지식을 볼 수 있는 방법으로 음운규칙이 적용되는 단
어들을 형태소 수에 따라 좀 더 세분화해서 차이가 있는지 살펴볼 필요가 있다. 그래서 본 연구에서는 우리나라 쓰기에서 음운대로 쓰는 단어와 음운규칙이 적용되는 단어 중에서 형태소가 1 개인 것 과 2개인 것, 좀 더 복잡한 겹자음이 포함된 단어로 철자유형을 나 누어 살펴보려고 한다. 이것은 철자쓰기에서 일반아동이 언어학습 장애 아동에 비해 형태소지식을 더 잘 활용할 가능성이 있다. 특히 읽기부진 아동들이 형태소지식의 부족으로 철자쓰기에 있어 전략 적인 도움을 받지 못한다는 기존 연구들을 토대로 본 연구의 대상 인 언어학습장애 아동과 일반아동의 철자쓰기능력에서 형태소 수 에 따라 수행력의 차이가 있는지도 살펴볼 필요가 있다.

더불어 아이들이 철자쓰기에서 나타나는 많은 오류유형들이 있 는데 선행연구에서 철자쓰기에서 오류분석을 통해 아동이 언어의 소리체계를 어떻게 이해하고 글자체계에 대한 논리를 전략으로 어 떻게 사용하는지 알아보기 위해 오류를 살펴보았다(Kim \& Yang, 2015). 본 연구에서도 선행연구(Kim, 2009)를 기반으로 철자오류 를 음운처리오류, 표기처리오류, 형태처리오류로 나누어 분석하고 자 한다.

본 연구에서는 철자쓰기 과제를 중심으로 철자유형(규칙단어, 형태소가 1 개인 불규칙단어, 형태소가 2 개인 불규칙단어, 겹자음 이 포함된 불규칙단어)과 음운규칙유형(격음화, 경음화, 연음화, 비 음화)에 따른 언어학습장애 아동과 일반아동의 철자쓰기 수행능 력을 알아보고자 한다. 이에 따라 설정한 연구문제는 다음과 같다.

1) 언어학습장애 아동과 일반아동은 철자유형에 따라 철자쓰기 수행능력에 유의미한 차이가 있는가?

2) 언어학습장애 아동과 일반아동은 음운규칙유형에 따라 철자 쓰기 수행능력에 유의미한 차이가 있는가?

3) 언어학습장애 아동과 일반아동의 철자쓰기에서 나타난 오류 의 특성은 무엇인가?

\section{연구방법}

\section{연구대상}

본 연구의 대상은 학년을 일치시킨 경기지역 내 초등학교 1-3학 년에 재학 중인 언어학습장애 아동 10명(1학년 5명, 2 학년 3명, 3 학 년 2명), 일반아동 10명(1학년 5명, 2학년 3명, 3학년 2명)으로 총 20 명의 아동이며, 아래와 같은 선정기준에 의해 선정되었다.

언어학습장애 아동은 (1) 보호자, 교사의 보고에 의해 시각적, 청 각적, 인지적, 정서 및 행동에 문제가 없는 아동, 2) 수용·표현어휘 력검사(Receptive \& Expressive Vocabulary Test, REVT; Kim, Hog, Kim, Jang, \& Lee, 2009)의 하위 항목인 수용어휘력검사 결과 해당 
Table 1. Characteristics of vocabulary and decoding skills between LLD and TD groups

\begin{tabular}{lccc}
\hline & $\operatorname{LLD}(\mathrm{N}=10)$ & $\mathrm{TD}(\mathrm{N}=10)$ & $t$ \\
\hline REVT-R & $74.20(9.76)$ & $96.67(9.62)$ & $5.81^{* *}$ \\
KOLRA decoding & $45.70(8.00)$ & $62.17(4.55)$ & $5.99^{* *}$ \\
\hline
\end{tabular}

Values are presented as mean (SD).

$\mathrm{LLD}=$ language learning disabilities; TD = typically developing children; $\mathrm{REVT}=$ Receptive \& Expressive Vocabulary Test (Kim, Hong, Kim, Jang, \& Lee, 2009); KOLRA=Korea Language-based Reading Assessment (Pae, Kim, Yoon, \& Jang, 2015). ${ }^{*} p<.05,{ }^{* *} p<.01$.

연령의 표준편차가 -1 SD 미만인 아동, (3) 한국어 읽기검사(Korea Language-based Reading Assessment, KOLRA; Pae, Kim, Yoon, \& Jang, 2015)의 하위 항목인 해독검사 결과 $25 \%$ ile 미만인 아동으 로 언어와 읽기에 어려움을 보이는 아동으로 선정하였다.

일반아동은 (1) 보호자, 교사의 보고에 의해 시각적, 청각적, 인지적, 정서 및 행동에 문제가 없는 아동, (2) 수용·표현어휘력검사(REVT; Kim et al., 2009)의 하위 항목인 수용어휘력검사 결과 해당 연령의 표준편차가 -1 SD 초과인 아동, (3) 한국어 읽기검사(KOLRA; Pae et al., 2015)의 하위 항목인 해독검사 결과 $25 \%$ ile 초과인 아동으로 언어능력뿐 아니라, 읽기에도 어려움을 보이지 않는 아동으로 선정 하였다(Table 1).

본 연구의 대상별 어휘, 읽기검사의 차이를 알아보기 위한 $t$-검정 결과 어휘 $(t=5.81, p<.01)$ 와 읽기검사 $(t=5.99, p<.01)$ 모두 두 집단 간 유의미한차이를 보였다.

\section{검사도구}

대상자 선정도구

수용·표현어휘력검사(REVT)

언어능력을 측정하기 위해 수용·표현어휘력검사(REVT) 중 수용 어휘검사를 실시하였다.

한국어 읽기검사(KOLRA)

읽기능력을 측정하기 위해 한국어 읽기검사(KOLRA) 중 해독검 사를 실시하였다.

\section{본 검사도구}

\section{검사단어 선정}

본 연구에 사용된 철자쓰기검사 과제는 선행연구(Deacon \& Bryant, 2005)를 기반으로 철자유형과 음운규칙을 고려하여 한국 어의 특성에 맞게 연구자가 직접 제작하였다. 검사 단어는 최소 3 회 이상 초등학교 $1,2,3$ 학년 국어과 교과서에 나오는 단어를 선정하
였으며, $\operatorname{Kim}$ (2003)의 '등급별 국어교육용 어휘'에서 1, 2등급 단어 를 선정하였다. 단어유형과 음운규칙에 맞는 단어를 선정하려다 보 니 3, 4등급 단어(석회, 꼭지, 망고)가 포함되었다. 그 중 '망고'는 교 과빈도가 적고 4 등급 단어이지만 일상생활에서 사용빈도가 높은 친숙한 어휘이기에 선정하였다. 모든 단어는 2음절로 구성하였고, 4 개유형의 단어(일치단어, 형태소가 1 개인 불일치단어, 형태소가 2 개인 불일치단어, 겹자음이 포함된 불일치단어)와 4 개의 음운규칙 (격음화, 경음화, 연음화, 비음화)으로 총 8세트로 구성되었다. 한 세트의 단어는 4개(망고-막내-막는-깎는)로 구성되어 있으며, 모두 음운규칙 적용되는 음절 위치에서 같은 소리가 나도록 일치시켰다. 일치한 단어가 없을 경우엔 최대한 같은 소리로 일치시켰다. 예를 들어 '깎는'의 경우 ‘망고-막내-막는'과 같이 '망'으로 일치시키려 하 였으나, 해당 단어를 찾지 못하여 소리 값 '앙'으로 조절하였으며, '석회'의 경우에는 ‘서쾨'로 발음되어 소리 값 '코'에 대한 'l' 모음이 삽입되었다.

철자유형: 철자유형은 자소-음소 일치단어와 불일치단어로 나 누었으며, 자소-음소 일치단어는 모두 한 개의 형태소로 구성된 단 어로 선정하였고, 불일치단어는 3 가지 유형으로 나누었다. 형태소 수에 따라 형태소가 1 개인 것과 형태소가 2 개인 것으로 나누었으 며, 형태소가 2 개인 것은 다시 종성자음의 수에 따라 겹자음이 포 함된 것과 포함되지 않는 것으로 나누었다.

음운규칙: 본 연구에서는 위의 단어를 음운규칙별 4 가지 세트로 구성하였다. Lee (2007)는 교과서의 학습내용이 주로 표준발음학 습과 관련이 있으며, 여기에는 자음·모음의 발음, 장·단음의 발음, 받침의 연음, 격음화, 받침의 중화, 겹받침의 발음, / ㄴ/ 소리의 발음, 경음화, 비음화, 유음화의 발음이 주 내용이라고 하였다. Lee와 Chung (2002)의 연구에서 한국어 음운규칙에 대한 통계적 분석 결과, 필수음운규칙의 경우 연음법칙, 경음법칙, 격음화, 장애음의 비음화 순으로 음운변화가 발생하였다. 이에 본 연구에서는 초등학 교 교과서에 나오는 음운규칙을 기준으로 한국어 필수음운규칙에 서 가장 많이 나오는 4가지 규칙인 격음화(특히), 경음화(꼭지), 연 음화(국어), 비음화(식물)를 포함시켰으며(Lee \& Chung, 2002), 4가 지 철자유형들이 음운규칙별로 들어갈 수 있도록 선정하였다.

철자유형과 음운규칙을 고려해 선정된 단어의 예는 Appendix 1 에 제시되어 있다.

\section{검사문장}

본 검사는 단어를 먼저 들려주고 단어가 포함된 문장(예문)을 들 
려주고 다시 단어를 불러주는 방식으로 진행되며, 이러한 절차를 사용하는 이유는 단어만 주어졌을 때 같은 소리가 나는 다른 단어 로 혼동할 수 있기 때문이다. 예를 들어, '익어'의 발음과 ‘이거'의 발 음은 '이거'로 동일하기 때문에 아동들이 단어를 이해하는 데 혼동 될 수 있다. 예문은 문장의 길이나 사용된 단어가 철자쓰기에 영향 을 미치지 않도록 3-5어절로 이루어졌으며, 목표어휘를 제외한 모 든 어휘는 1 학년 교과에서 선정하였고, 문장의 이해에 어려움이 없 도록 행위자가 행위에 대한 주체가 주어일 경우에는 최대한 주어를 '나'로 통일시켰는데 부득이하게 주어가 ‘나’로 통일되지 않은 경우 에는 가족 구성원(예: 할머니, 동생)을 주어로 문장을 구성하였다. 본 연구를 위해 개발된 철자쓰기 검사도구가 초등 저학년 아동의 철자능력을 적절하게 평가하고 있는지 알아보기 위해 내용타당도 조사를 실시하였다. 타당도 조사는 Likert 5점 척도(매우적절, 적 절, 보통, 부적절, 매우 부적절)로 구성되었으며, 언어병리학을 전공 한 박사학위소지자 2 명, 특수교육학을 전공한 박사학위소지자 1 명, 총 3 명에게 의뢰하였다. 타당도 조사 항목은 단어와 문장의 적절성 으로 구성되었으며, 조사 결과 단어평균 4.9 , 문장평균 4.96 으로 나 타났다.

\section{연구절차}

\section{예비실험}

본 검사를 실시하기 전, 경기지역 내 초등학교에 다니고 있는 1학 년 아동 3 명을 대상으로 철자쓰기검사에 포함된 단어 및 예문의 이 해도를 확인하기 위해 예비검사를 실시하였다. 예비검사에서 사용 한 검사문항은 과제유형별 8 개씩 총 32 개 단어로 구성하였다. 예비 검사 결과 세 아동이 검사 단어와 제시된 문장의 대부분을 이해하 고 철자하는 데 큰 문제가 없었다. 하지만 ‘공부하기 싫음 말아라’의 경우 문장의 의미를 이해하지 못해 '공부하기 싫음 하지 말아라'라 고 수정해 주었을 때 이해하였기 때문에 최종 검사문항 선정에서 수정하였다.

\section{본 실험}

\section{선정검사}

아동의 어휘력을 알아보기 위해 수용·표현어휘력검사(REVT) 중 수용어휘검사를 실시하였으며, 읽기 가능여부를 확인하기 위해 한국어 읽기검사(KOLRA)의 하위항목인 해독검사를 실시하였다.

\section{철자쓰기 검사}

본 연구를 위해 2017년 1월부터 2월까지 경기지역 내 초등학교를 다니고 있는 1-3학년 아동을 대상으로 연구자가 개발한 철자쓰기
검사과제를 이용해 검사를 진행하였다. 검사장소는 아동의 집이나 학원교실 등의 조용한 곳에서 실시하였다. 검사자는 검사 전 예시 문제를 활용하여 아동에게 검사방법에 대해 충분히 설명한 후 검 사를 진행하였다. 검사방법은 검사 시 동음어에 대한 혼란을 피하 기 위해 각 문제마다 검사 단어를 불러주고 단어가 포함된 문장을 불러 준 다음, 다시 검사 단어를 불러주는 방식으로 진행하였다. 검 사자는 아동에게 크고 정확한 소리로 과제를 한번 들려주는 것을 원칙으로 하였으며, 아동이 재요청 시에는 단어, 문장, 단어 순서로 1 번 더 들려주었다. 검사순서는 격음화, 경음화, 연음화, 비음화 순 서로 불러주어 목표단어를 받아쓰게 하였다. 아동은 미리 나누어 준 종이에 이름과 생년월일을 쓰고 단어만 해당 번호에 철자하도록 하였으며, 약 15-20분 정도 소요되었다.

\section{자료분석}

\section{철자쓰기 채점방법}

채점은 각 단어의 목표철자를 정확하게 철자하였을 경우 1 점, 그 렇지 못한 경우 0 점, 총 32 점 만점으로 산출하였다. 철자유형별 점 수는 일치단어 8 점, 형태소가 1 개인 불일치단어 8 점, 형태소가 2 개 인 불일치단어 8점, 겹자음이 포함된 불일치단어 8점으로 구성되 었으며, 음운규칙별 점수는 격음화 8점, 경음화 8점, 연음화 8점, 비 음화 8점으로 구성되었다.

\section{오류 분석}

아동의 철자오류에 대한 분석은 Kim (2009)의 연구에서 사용된 오류분석 방법을 참고하였으며, 본 연구에서는 언어학습장애 아동 과 일반아동별 자소-음소 일치단어와 음운규칙이 적용되는 단어로 나누어 철자쓰기에서 나타난 오류유형 및 오류율을 살펴보고, 오류 유형을 ‘음운처리오류, 표기처리오류, 형태처리오류’로 구분하여 분 석하였다. 만일 하나의 단어에서 2 개 이상의 오류가 발생한 경우에 는 중복 카운팅을 하였다(예: ‘좋기'를 '조키'로 철자한 경우, 음운처 리오류와 표기처리 오류에 각 1 점씩 부여). 아동의 오류유형별 점수 는 오류율로 계산하여 분석하였다. 오류율을 계산한 방법은 아래와 같으며, 산정한 값은 소수 둘째 자리에서 반올림하여 산출하였다.

$$
\text { 오류율 }=\text { 오류유형별 점수/아동의 전체오류 점수 }
$$

오류분석 기준에 대한 조작적 정의와 오류의 예는 Appendix 2 에 제시되어 있다.

\section{자료의 통계처리}

본 연구에서 수집된 자료를 SPSS version 20.0 Windows용 프로 
그램을 사용하여 다음과 같이 분석하였다.

언어학습장애 아동과 일반아동의 형태처리유형 및 음운규칙유 형에 따라 철자쓰기 수행능력을 알아보기 위해 반복측정 이원분 산분석(repeated two-way ANOVA) 후 사후검정으로 집단별 차이 를 알아보기 위해 독립표본 $t$-검정을 실시하였으며, 과제유형별 차 이를 살펴보기 위해 대응표본 $t$-검정을 실시하였다.

\section{신뢰도}

신뢰도를 측정하기 위해 언어병리전공 석사과정 학생 1 명을 대 상으로 채점기준과 오류분류 기준 등을 상세히 설명한 후 검사지 의 $20 \%$ 를 제 2 채점자가 독립적으로 점수를 산출하고, 오류분석 기 준에 따라 오류를 분석하도록 하여 신뢰도를 산출하였다. 신뢰도 측정결과 철자쓰기 채점 신뢰도는 $99 \%$, 오류분석 신뢰도는 $96 \%$ 로 나타났다.

\section{연구결과}

\section{철자유형에 따른 철자쓰기 수행능력}

언어학습장애 아동과 일반아동의 철자유형에 따라 철자쓰기 수 행능력에 대한 기술통계 결과는 Table 2와 같다.

기술통계 결과, 언어학습장애 아동은 일치단어, 형태소가 1 개인 불일치단어, 형태소가 2 개인 불일치단어, 겹자음이 포함된 불일치 단어 순으로 평균이 높았다. 일반아동은 일치단어가 가장 평균이 높았으며, 형태소가 2 개인 불일치단어, 형태소가 1 개인 불일치단 어, 겹자음이 포함된 불일치단어 순으로 나타났다. 즉, 언어학습장 애 아동과 일반아동 모두 일치단어의 평균이 가장 높았으며, 겹자 음이 포함된 불일치단어가 가장 낮았다. 그러나 형태소가 1 개인 불 일치단어의 평균이 형태소가 2 개인 불일치단어의 순위는 두 집단 이 다른 경향을 보였다.

이러한 차이가 통계적으로 유의미한 것인가를 확인하기 위해 반

Table 2. Descriptive statistics of spelling according to the types of spelling

\begin{tabular}{lrl}
\hline Type & $L L D(N=10)$ & $T D(N=10)$ \\
\hline MW & $5.90(1.85)$ & $7.40(.52)$ \\
$1 N W$ & $3.50(2.76)$ & $6.70(1.16)$ \\
$2 N W$ & $2.90(2.42)$ & $7.10(.74)$ \\
DNW & $.90(1.29)$ & $4.50(1.72)$ \\
\hline
\end{tabular}

Values are presented as mean (SD).

$\mathrm{LLD}=$ language learning disabilities; $\mathrm{TD}=$ typically developing children; $\mathrm{MW}=$ lettersound matching word; $1 \mathrm{NW}=$ grapheme-phoneme nonmatching word with one morpheme; 2NW = letter-sound nonmatching word with two morphemes; DNW = lettersound nonmatching word with double consonant.
복측정 이원분산분석을 실시한 결과 집단 간 유의미한 차이를 보 였는데 $(F=26.96, p<.01)$ 이는 일반아동이 언어학습장애 아동보 다 철자쓰기 수행능력이 더 높은 것을 보여준다. 또한 철자유형에 따른 차이도 유의미하게 나타났으며 $(F=34.60, p<.01)$, 이 차이가 어떤 철자유형 간에서 나타났는지 알아보기 위해 대응표본 $t$-검정 을 실시한 결과 형태소가 1 개인 불일치단어와 형태소가 2 개인 불일 치단어 $(t=0.33, p>.05)$ 에서는 유의한 차이가 없었으나 다른 유형 들 간에는 모두 유의미한 차이가 나타났다.

또한 집단과 철자유형 간의 상호작용효과가 나타났다 $(F=4.38$, $p<.01)$. 언어학습장애 아동은 형태소가 1 개인 불일치단어의 평균 이 형태소가 2 개인 불일치단어의 평균보다 더 높게 나타났으며, 반 대로 일반아동은 형태소가 2 개인 불일치단어의 평균이 더 높게 나 타나는 경향을 보였다. 즉, 형태소가 1 개인 불일치단어와 형태소가 2 개인 불일치단어 사이에 두 집단의 패턴이 조금 다르게 나타났다. 철자유형에 따라 두 집단이 유의미하게 차이가 나는지 알아보기 위해 독립표본 $t$-검정을 실시한 결과 모든 철자유형에서 유의미한 차이를 보였다. 즉, 언어학습장애 아동이 일반아동에 비해 낮은 수 행능력을 보였다. 철자유형에 따른 두 집단의 수행력 차이는 Figure 1 에서 살펴볼수 있다.

\section{음운규칙유형에 따른 철자쓰기 수행능력}

언어학습장애 아동과 일반아동이 보이는 음운규칙유형에 따른 철자쓰기 수행능력에 대한 기술통계 결과는 Table 3에 제시되어 있다.

기술통계 결과, 언어학습장애 아동은 비음화, 경음화, 연음화, 격 음화 순으로 평균이 높았고, 일반아동은 비음화, 연음화, 경음화, 격음화 순으로 평균이 높아 다소 다른 경향을 보여주었다. 즉, 언어 학습장애 아동과 일반아동 모두 경음화에서 가장 낮은 점수를, 비

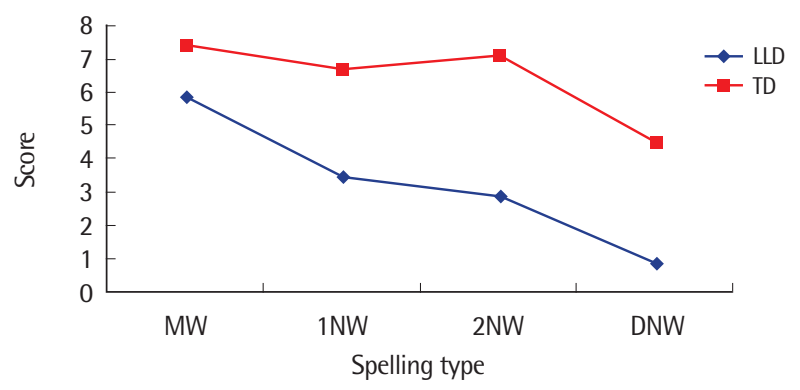

Figure 1. Spelling types between LLD and TD groups. LLD = language learning disabilities; TD = typically developing children; $\mathrm{MW}=$ letter-sound matching word; $1 \mathrm{NW}=$ grapheme-phoneme nonmatching word with one morpheme; 2NW = letter-sound nonmatching word with two morphemes; DNW= letter-sound nonmatching word with double consonant. 
Table 3. Descriptive statistics of spelling according to phonological rules

\begin{tabular}{lcl}
\hline Phonological rule & $\operatorname{LD}(\mathrm{N}=10)$ & $\mathrm{TD}(\mathrm{N}=10)$ \\
\hline Aspiration & $1.20(1.87)$ & $3.30(1.89)$ \\
Fortification & $2.00(1.05)$ & $4.20(1.03)$ \\
Lenition & $1.50(1.35)$ & $4.80(.79)$ \\
Nasalization & $2.80(1.93)$ & $4.90(.99)$ \\
\hline
\end{tabular}

Values are presented as mean (SD).

$L L D=$ language learning disabilities; $T D=$ typically developing children .

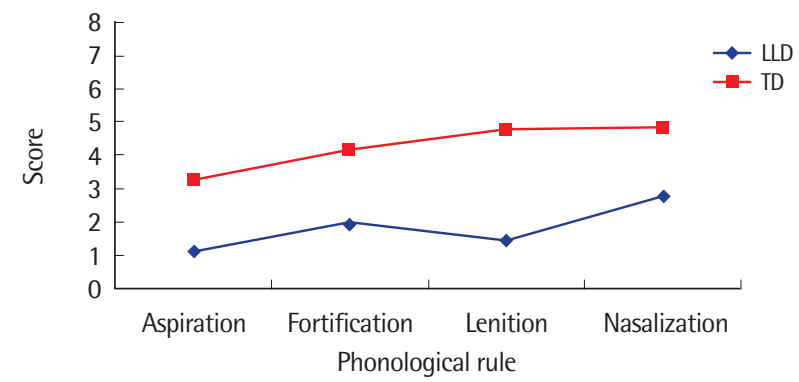

Figure 2. Phonological rules between LLD and TD groups.

$\mathrm{LLD}=$ language learning disabilities; $\mathrm{TD}$ = typically developing children.

음화에서는 가장 높은 점수를 받았으며, 연음화에서는 언어학습 장애 아동이 일반아동과의 차이가 가장 많이 났다. 이는 언어학습 장애 아동이 일반아동에 비해 연음화에서 더 많은 어려움을 보인 다는 것을 알 수 있다. 음운규칙에 따른 두 집단 아동의 수행력은 Figure 2에 제시되어 있다.

이러한 차이가 통계적으로 유의미한 것인가를 확인하기 위해 반 복측정 이원분산분석을 실시한 결과 집단 간 차이가 통계적으로 유의미하였다 $(F=28.03, p<.01)$. 이는 음운규칙이 적용된 철자쓰 기에서 언어학습장애 아동이 일반아동에 비해 철자쓰기 수행능력 이 더 낮다는 것을 나타낸다. 또한 집단 내 요인으로 음운규칙유형 에 따른 수행능력의 차이가 유의미하게 났는데 $(F=6.40, p<.01)$, 이 러한 차이가 어느 음운규칙유형에서 비롯되었는지 알아보기 위해 대응표본 $t$-검정을 실시한 결과 격음화와 비음화 $(t=-4.88, p<.01)$, 경음화와 비음화 $(t=-2.38, p<.01)$ 유형 간 차이가 유의미하였다. 또한 집단과 음운규칙유형 간 상호작용 효과는 유의미하지 않았는 데( $F=1.28, p>.05)$, 이는 두 집단 간 음운규칙 유형에 따른 철자쓰 기 수행력의 패턴이 유사한 것으로 해석할 수 있다. 음운규칙유형 별 두 집단이 유의미하게 차이가 나는지 알아보기 위해 $t$-검정을 실 시한 모든 유형에서 두 집단 간 차이가 유의미하게 나타났다.

\section{철자쓰기에 나타난 오류유형 및 빈도}

언어학습장애 아동과 일반아동의 오류유형에 따른 빈도 및 오
Table 4. Descriptive statistics of error types

\begin{tabular}{lrrr}
\hline & LLD $(\mathrm{N}=10)$ & TD $(\mathrm{N}=10)$ & \multicolumn{1}{c}{ Total } \\
\hline Phonological error & $149(43.4)$ & $63(49.2)$ & $212(100)$ \\
Orthographical error & $110(32.1)$ & $43(33.6)$ & $153(100)$ \\
Morphological error & $84(24.5)$ & $22(17.2)$ & $106(100)$ \\
Total & $343(100)$ & $128(100)$ & $471(100)$ \\
\hline
\end{tabular}

Values are presented as frequency $(\%)$.

$\mathrm{LLD}=$ language learning disabilities; $T D=$ typically developing children .

류율은 Table 4 와 같다.

언어학습장애 아동은 오류유형 중 음운처리오류 149\% (43.4\%), 표기처리오류 $110 \%$ (32.1\%), 형태처리오류 84\% (24.5\%) 순으로 오 류빈도가 높았다. 일반아동은 음운처리오류 63\% (49.2\%) 표기처리 오류 43\% (33.6\%), 형태처리오류 22\% (17.2\%) 순으로 오류빈도가 높았다. 즉, 언어학습장애 아동과 일반아동 모두 비슷한 오류패턴 을 보여주었다.

\section{논의 및 결론}

본 연구는 학년을 일치시킨 1-3학년 언어학습장애 아동과 일반 아동을 대상으로 철자유형과 음운규칙유형에 따른 철자쓰기 수행 능력의 차이를 알아보고, 철자쓰기에 나타난 오류유형 및 빈도를 알아보았으며 연구결과에 대한 논의는 다음과 같다.

첫째, 언어학습장애 아동과 일반아동의 철자유형에 따른 철자 쓰기 수행능력의 차이를 살펴본 결과, 언어학습장애 아동과 일반 아동 간의 유의미한 차이가 있는 것으로 나타났다. 즉, 언어학습장 애 아동의 철자쓰기 수행능력은 일반아동의 철자쓰기 수행능력에 비해 유의미하게 낮다고 볼 수 있다. 이러한 차이는 읽기장애 아동 을 대상으로 한 Kim (2015)의 연구에서도 읽기장애 아동이 일반아 동에 비해 철자법이 정확도가 낮다고 보고한 연구결과와 유사하 다. 또한 철자부진 아동을 대상으로 한 Kim (2013)의 연구에서도 1,2 학년 철자부진 아동이 일반아동에 비해 철자쓰기 수행능력 점 수가 낮다고 보고되어있는데 이 또한 본 연구결과와 비슷하다.

본 연구결과 철자유형에 따라 통계적으로 차이가 났으며, 일치단 어와 나머지 세 가지 유형들과 차이가 났다. 이는 일치단어보다 불 일치단어에서 쓰기에 더 어려움이 있다는 것을 보여준다. Choi 등 (2011)의 연구결과 일반아동과 읽기장애 아동 모두 음운규칙적용 유무에 따라 유의미한 차이가 났으며, Kim, Choi와 Kim (2010)의 연구에서도 철자부진 아동과 일반아동 모두 규칙단어와음운규칙 이 적용된 단어에서 유의미한 차이를 보였다. 이러한 결과는 읽기 장애 아동과 철자부진 아동, 일반아동 모두 불일치단어보다 일치 
단어에서 철자쓰기 수행능력이 더 좋다는 것을 의미하며, 언어학 습부진 아동을 대상으로 한 본 연구결과에서도 이와 같은 결과를 지지해주고 있다.

그런데 본 연구에서는 불일치단어를 좀 더 구체적으로 살펴보기 위해서 불일치단어를 형태소 수의 차이와 겹자음 유무에 따라 3 가 지 유형으로 나누어 살펴 보았다. 그 결과 종성에 겹자음이 포함된 복잡한 음절구조의 단어는 다른 두 유형에 비해서 두 집단 아동 모 두 철자쓰기에서 현저하게 낮은 점수를 받았다. Kim (2009) 연구 에서 학습부진 아동과 일반아동을 대상으로 겹받침이 적용된 철 자쓰기 수행능력을 살펴본 결과 두 집단 모두 1 학년 때 겹받침이 적 용되는 단어의 철자쓰기 수행능력 수준이 낮았다. 이는 본 연구대 상자가 주로 1,2 학년에 해당되는 것을 생각해볼 때 본 연구결과와 같은 맥락이다. 이러한 연구들을 통해서 아이들이 철자쓰기에서 음절구조의 복잡성이 철자쓰기에 있어 어려움을 더 초래한다는 것 을 해석해 볼 수 있다. 이는 겹받침이 다른 음운변동과 동시에 적용 될 경우 단어에서 오류가 높게 나타난다는 선행연구의 결과와도 일 치한다(Kim, 2009).

Deacon과 Bryant (2005)의 연구에서 5-10세의 일반아동들을 대 상으로 연구한 결과 1 형태소와 2 형태소로 나누어 같은 소리가 나 는 2형태소 단어에 대해 형태소지식을 사용하여 1 형태소 단어보다 더 정확하게 철자하였다. 즉, 철자쓰기를 할 때 형태소지식이 있는 아동들은 형태전략을 사용하여 철자한다는 것을 보여주었다. 그런 데 본 연구결과에서는 Deacon과 Bryant (2005)의 연구와 달리 형 태소 수에 따라 차이가 유의미하게 나타나지 않았다. 그런데 외국 연구를 보면, Green 등(2003)은 3, 4학년을 대상으로 연구한 결과 3 학년 보다는 4 학년에 굴절어를 더 정확하게 사용하였으며, 4 학년 이후에는 파생어를 적절하게 사용할 수 있을 것으로 보았다. 6-10 세 아동을 대상으로 한 Sangster와 Deacon (2011)의 연구에서도 나 이가 많은 아동(9세)은 1 형태소 단어보다는 2형태소 단어를 더 바 르게 철자하였으나, 7세 아동들에게서는 이런 특징이 나타나지 않 았다고 한다. Henderson (1990)의 연구에서는 초등학교 저학년 아 동들이 철자쓰기에 있어 주로 음운전략을 사용하며 형태전략을 사용하는 데는 어려움이 있다고 하였는데, Apel, Diehm과 Apel (2013)의 연구에서 초등 1 학년과 2 학년을 대상으로 일주일에 4 번씩 기본 단어와 그 단어의 굴절과 파생어 사이의 관계에 대한 중재 결 과, 2 학년 아동들에게서 유의미한차이가 났다.

이와 같은 연구들을 볼 때, 고학년에서 형태전략을 사용한다는 일관적인 결과를 보여주었으나, 저학년의 경우에는 외국연구에서 도 일관되지 않는 결과를 보여주었다. ‘꼭지'의 '지'와 ‘먹지'의 어미 '-지'가 둘다 '-찌'로 들렸을 때 '가지, 사지' 등의 형태지식을 활용해
‘꼭지’보다 ‘먹지’를 더 정확히 쓸 것이라고 가설을 세워 보았지만 이 두 유형의 차이가 유의미하게 나타나지는 않았다. 즉, 본 연구대상 인 초등 저학년 아동의 경우 철자하기에서 형태지식을 적용한 쓰 기를 더 잘하는 것은 아니라는 결과가 나타났다. 이러한 연구결과 는 본 연구의 주 대상이 저학년이었다는 점, 특히 $1,2,3$ 학년을 모두 포괄하고는 있으나 주로 1,2 학년이 많았던 점을 고려해볼 때 저학 년 아동들은 철자쓰기에 있어 형태전략을 사용하는 데 어려움이 있다고 해석해볼 수 있다. 이는 Sangster와 Deacon (2011)과 Henderson (1990)의 선행연구 결과를 지지해준다. 또한 두 집단 아동 들이 형태소 인식능력의 차이에 대한 정보도 부족하여 철자하기와 형태소지식 간의 관련성을 면밀히 살펴보는 데는 제한점이 있을 수 있다. 이에 대해 후속연구에서는 형태소지식과 철자하기의 관련성 을 밝혀보고, 초등 중학년 이후 고학년까지로 대상을 좀 더 확장해 서 살펴볼 필요가 있겠다.

다만, 본 연구결과에서는 집단과 철자유형 간의 상호작용효과가 나타났다. 언어학습장애 아동은 일반아동에 비해 형태소가 1 개인 불일치단어를 형태소가 2 개인 불일치단어보다 평균점수가 더 높았 고, 일반아동은 언어학습장애 아동에 비해 형태소가 1 개인 불일치 단어보다 형태소가 2 개인 불일치단어의 평균점수가 더 높았다. 형 태소가 1 개인 불일치단어와 형태소가 2 개인 불일치단어의 통계적 인 차이는 없지만 상호작용에서 이러한 차이를 보인 것으로 보아 일반아동이 언어학습장애 아동보다 형태소지식을 좀 더 사용할 가능성을 보여주는 경향성이 나타났다는 점이 흥미롭다. 이러한 경향이 나타나는 것은 주목할 필요가 있으며, 좀 더 고학년을 대상 으로 확대하여 살펴보았을 때 형태소지식을 더 잘 사용할 수 있을 것으로 예측된다. 우리나라에서도 형태전략을 학령전기부터 노출 이 많을 경우 사용하는 경향을 보인다는 Yang (2009)의 연구를 볼 때 일반아동에게는 형태소지식이 철자쓰기에 활용되는 경향을 보 이는 것 같다. 그러나 여전히 언어학습부진 아동은 본 연구의 과제 에서 노출이 많은 친숙한 단어들을 사용했음에도 불구하고 형태 전략의 이득을 보지 못하는 것 같다. 그럼에도 불구하고 언어학습 장애 아동이 일반아동에 비해 형태지식을 활용하는 데 제한점이 있다는 해석은 주의가 필요하다.

둘째, 언어학습장애 아동과 일반아동의 음운규칙유형에 따른 철자쓰기 수행능력의 차이를 살펴본 결과, 언어학습장애 아동과 일반아동은 유의미한 차이를 보였다. 즉, 일반아동이 언어학습장 애 아동보다 더 높은 수행능력을 보였으며, 이것은 읽기장애 아동 과 일반아동을 대상으로 한 Choi 등(2011)연구에서 중화규칙, 겹 받침단순화, 격음화, 연음규칙, 자음동화 받침철자에서 집단 간 유 의미한차이를 보였으며, 인공와우이식 아동과 일반아동을 대상으 
로 한 $\operatorname{Kim}$ (2012)의 연구에서도 음운규칙단어 중 장애음의 비음 화, 설측음의 비음화, 설측음화, 겹받침에서 집단 간 유의미한 차이 를 보인 결과와 비슷하다.

본 연구에서는 두 집단 모두 격음화에서 가장 낮은 점수를 받았 고, 비음화에서 가장 높은 점수를 받았으며, 연음화에서는 언어학 습장애 아동이 일반아동에 비해 더 많은 어려움을 보였다. Song, Shin과 Pae (2016)의 연구에서 언어·읽기부진 집단과 일반아동 집 단을 대상으로 언어.읽기능력, 과제유형 및 연음유형에 따른 해독 과 철자수행능력을 살펴본 결과, 일반아동보다 언어.읽기부진 아 동에서 연음유형에 따른 수행 격차가 큰 것으로 나타났으며, 초등 저학년 시기에 국어교육지도에서 연음규칙에 대한 이해와 지도가 매우 중요하다고 하였다. 본 연구결과에서는 통계적으로는 차이가 나지 않았는데 다른 음운규칙에 비해 연음화에서 두 집단 간 평균 차이가 컸다는 점에서는 언어학습장애 아동들의 연음규칙 수행능 력에 대해 좀 더 검토해볼 필요가 있다. 또한 본 연구에서는 음운규 칙유형과 집단간 상호작용효과는 나타나지 않았다.

셋째, 언어학습장애 아동과 일반아동의 오류유형 및 빈도를 분 석한 결과, 본 연구에서는 언어학습장애 아동과 일반아동 모두 음 운처리오류가 가장 높았으며, 표기처리오류, 형태처리오류 순으로 나타났다. 이는 언어학습장애 아동과 일반아동의 오류율의 순서 가 같게 나타났는데 $\operatorname{Kim}$ (2009)의 연구에서 두 집단의 오류빈도 순서가 같았다는 보고와 비슷하다. Kim, Kim, Kim, Lee와 Lee (2013)의 연구에서 청각장애 아동 1,3 학년을 대상으로 연구한 결 과, 1 학년 청각장애 아동은 음운처리오류, 표기처리오류, 기타오류, 형태처리오류 순으로 연구대상은 다르나 본 연구결과와 비슷하게 나타났다. 그러나 3 학년 청각장애 아동은 표기처리, 음운처리, 형태 처리 순으로 나타나 본 연구결과와 차이를 보였다. 본 연구의 대상 자가 대부분 1,2 학년으로 구성되어 있어 유사한 연구 결과를 보인 것으로 해석할 수 있다. 또한 $\operatorname{Kim}$ (2009)은 1-6학년 일반아동과 철 자부진 아동을 대상으로 살펴본 결과, 표기처리오류, 음운처리오 류, 형태처리오류 순으로 오류가 높게 나타났으며 본 연구 결과와 는 다소 차이를 보였다. 이것은 $\operatorname{Kim}(2009)$ 의 연구에서 규칙단어와 불규칙단어의 비율을 보았을 때, 불규칙단어의 비율이 본 연구보 다 훨씬 많았던 것이 작용했을 것 같다. 왜냐하면, 자소-음소 일치 단어에서는 표기처리오류가 나타날 가능성이 적은 것에 비해 불일 치단어의 경우에는 표기처리오류가 나타날 가능성이 높기 때문에 불규칙단어가 본 연구과제 보다 더 많았던 Kim (2009)의 연구에서 표기처리오류의 빈도가 더 높았던 것으로 보인다.

위의 결과로 보아 언어학습장애 아동은 일반아동에 비해 철자 유형 및 음운규칙유형에 따라 철자쓰기 수행능력이 유의미하게 낮
다는 것을 알 수 있었으며, 이는 추후 언어학습장애 아동을 대상으 로 철자쓰기 지도를 할 경우, 철자유형 및 음운규칙유형을 고려하 여 지도할 필요가 있음을 보여주었다.

또한 형태소 수에 따라 일반아동과 언어학습장애 아동이 철자 쓰기에서 다른 패턴을 보이는 것을 확인할 수 있었다. 본 연구에서 는 통계적으로 유의미한 차이는 없었으나 언어학습장애 아동보다 일반아동이 철자쓰기에 있어 형태소지식을 사용할 가능성이 있음 을 보여준다.

하지만 본 연구는 학년별 사례수가 소수이고, 특히 3학년의 경우 2 명이 포함되어 있어 초등 저학년 전체를 대표하는 샘플로 구성되 지 못한 점에 대한 주의 깊은 해석이 필요하다. 따라서 후속연구에 서는 대상아동의 연령을 고학년으로 확대하여 형태소 수를 고려 한 철자쓰기에서 형태소지식의 사용에 대해 좀 더 연구해볼 필요 가 있는 것으로 사료된다.

\section{REFERENCES}

Adams, M. J. (1990). Beginning to read: learning and thinking about print. Cambridge, MA: MIT Press.

Apel, K. (2011). What is orthographic knowledge? Language, Speech, and Hearing Services in Schools, 42, 592-603.

Apel, K., Diehm, E., \& Apel, L. (2013). Using multiple measures of morphological awareness to assess its rela-tion to reading. Topics in Language Disorders, $33,42-56$.

Bear, D. R., Invernizzi, M., Templeton, S. R., \& Johnston, F. R. (2016). Words their way: word study for phonics, vocabulary, and spelling instruction (4th ed.). Upper Saddle River, NJ: Pearson.

Butler, K. G., \& Silliman, E. R. (2002). Speaking, reading, and writing in children with language learning disabilities: new paradigms in research and practice. Mahwah, NJ: Lawrence Erlbaum Associates.

Choi, Y. J., Kim, Y. T., Yun, H. R., \& Sung, J. E. (2011). Spelling ability of the final consonants in children with reading disabilities. Korean Journal of Communication \& Disorders, 16, 154-170.

Chung, B. J. (2015). Orthographic awareness and related components in children in grade 1 through 4. Journal of Speech-Language \& Hearing Disorders, 24, 63-71.

Deacon, S. H., \& Bryant, P. (2005). What young children do and do not know about the spelling of inflections and derivations. Developmental Science, 8 , 583-594.

Frith, U. (1985). Beneath the surface of developmental dyslexia. In K. Patter- 
son et al. (Eds.), Surface dyslexia (pp. 301-330). London: Taylor and Francis.

Ga, K. S. (2006). The relation between reading ability and reader's cognitive variables. Journal of Reading Research, 15, 243-269.

Green, L., McCutchen, D., Schwiebert, C., Quinlan, T., Eva-Wood, A., \& Juelis, J. (2003). Morphological development in children's writing. Journal of Educational Psychology, 95, 752-761.

Henderson, E. H. (1990). Teaching spelling (2nd ed.). Boston, MA: Houghton Mifflin.

Heo, H., Kwag, K. M., \& Lee, Y. (2011). The relationship among the reading and writing abilities and oral language skills of school-aged low-achievers in language learning. Korean Journal of Communication \& Disorders, 16, 23-33.

Jo, H., Kim, S., \& Jeong, J. (2006). The effects of children's phonological awareness and reading abilities on their writing abilities. Korean Journal of Early Child Education, 26, 371-388.

Jung, H., \& Kim, W. (2012). A comparative study on the effective reading comprehension strategy in children with reading disabilities: retelling and writing. The Journal of the Korean Association on Developmental Disabilities, 16, 45-73.

Jung, K. H. (2014). Morphological awareness and reading ability of schoolaged children from grades 1 to 3. Communication Sciences \& Disorders, 19, 21-30.

Kim, A. H. (2009). Spelling skills of elementary students in Korea: focusing on spelling accuracy and error patterns. Journal of Elementary Education, 22, 85-113.

Kim, A. H. (2013). A preliminary study on predictors for elementary students' writing. Communication Sciences \& Disorders, 18, 66-75.

Kim, A. H., Choi, H. N., \& Kim, J. H. (2010). Spelling skills of students with or without spelling difficulties in Korea: focusing on spelling accuracy and error patterns. Journal of Special Education, 45, 203-223.

Kim, B., \& Yang, M. (2015). Articulatory information for spelling strategies. Communication Sciences \& Disorders, 20, 400-412.

Kim, E. H., \& Jung, K. H. (2015a). Morphological awareness of 1st to 3rd grade school-aged children from mul-ticultural families. Communication Sciences \& Disorders, 20, 319-330.

Kim, J. (2016). Characteristics of reading related factors in subgroups with Language learning disorders. Journal of Learner-Centered Curriculum and Instruction, 16, 339-353.

Kim, K. (2003). Vocabularies for different levels of Korean education. Seoul: Pagijung.
Kim, S. H., \& Jung, K. H. (2015b). Morphological awareness and reading abilities for early elementary school students with poor reading skill. Journal of Speech \& Hearing Disorders, 24, 35-47.

Kim, Y. T., Hong, G. H., Kim, K. H., Jang, H. S., \& Lee, J. Y. (2009). Receptive \& expressive vocabulary test (REVT). Seoul: Seoul Community Rehabilitation Center.

Kim, Y. W. (2012). The characteristics of spelling skills of children with cochlear implants. Korean Journal of Special Education, 47, 1-17.

Kim, Y. W. (2015), A comparison of word recognition and spelling skills between students with reading disabilities and without disabilities. The Journal of Special Education: Theory and Practice, 16, 363-386.

Kim, Y. W., Kim, J. S., Kim, S. Y., Lee, Y. S., \& Lee, H. J. (2013), An analysis of spelling abilities in elementary students with hearing impairments. Special Education Research, 12, 43-60.

Ko, S. (2014). Comparing spelling ability between ADHD and normal children. The Korean Journal of Learning Disabilities, 11, 261-274.

Kwon, S. O. (2004). Effect of CIRC cooperative learning program on the reading and writing ability in learning disabled children (Master's thesis). Pusan National University, Busan, Korea.

Lee, C. (2007). Principle of grammar education in elementary school. Journal of Korean Language Education, 41, 127-148.

Lee, K., \& Chung, M. (2002). Statistical analysis of Korean phonological variations using grapheme-to-phoneme system. The Journal of the Acoustical Society of Korea, 21, 656-664.

Liberman, I. Y., \& Liberman, A. M. (1990). Whole language vs. code emphasis: underlying assumptions and their implications for reading instruction. Annals of Dyslexia, 40, 51-76.

Owens, R. E. (2012). Language development: an introduction (8th ed.). Boston, MA: Pearson.

Pae, S., Kim, M., Yoon, H. J., \& Jang, S. (2015). Korean Language Based Reading Assessment (KOLRA). Seoul: Hakjisa.

Pennington, B. F., \& Bishop, D. V. (2009). Relations among speech, language, and reading disorders. Annual Review of Psychology, 60, 283-306.

Sangster, L., \& Deacon, S. H. (2011). Development in children's sensitivity to the role of derivations in spelling. Canadian Journal of Experimental Psychology, 65, 133-142.

Scott, C. (2004). Syntactic ability in children and adolescents with language and learning disabilities. In R. A. Berman (Ed.), Language development across childhood and adolescence (pp. 111-133). Amsterdam: John Benjamins Publishing. 
Scott, C. (2005). Learning to write. In A. G. Kamhi \& H. W. Catts (Eds.), Language and reading disabilities (2nd ed., pp. 244-268). Boston, MA: Pearson.

Song, Y., Shin, G. Y., \& Pae, S. (2016). Decoding and spelling abilities of Korean first and second graders with and without language reading difficulties. Journal of Speech-Language \& Hearing Disorders, 25, 97-107.

Treiman, R., \& Cassar, M. (1996). Effects of morphology on children's spelling of final consonant clusters. Journal of Experimental Child Psychology,
$63,141-170$.

Yang, M. (2009). Spelling development of kindergarten students: a one year longitudinal study. Korean Journal of Communication \& Disorders, 14, 1433.

Yang, M. (2014). Children's spelling of phonological and morphological features in primary grades. Communication Sciences \& Disorders, 19, 120-131. 
Appendix 1. 철자쓰기 단어과제 및 제시 문장의 예

\begin{tabular}{|c|c|c|c|c|}
\hline 음운 규칙 & & 태 & 단어 & 문장 \\
\hline \multirow[t]{8}{*}{ 격음화 } & 자소-음소 일치 & & 스키 & 나는 스키 타기를 좋아한다. \\
\hline & 자소-음소 불일치 & 1형태소 & 특히 & 나는 특히 고기를 좋아한다. \\
\hline & & 2형태소 종성-단일자음 & 좋기 & 맛이 좋기 때문에 사람이 많다 \\
\hline & & 2형태소 종성-겹자음 & 많기 & 사람들이 많기 때문에 시끄럽다. \\
\hline & 자소-음소 일치 & & 결코 & 나는 결코 도망가지 않겠다. \\
\hline & 자소-음소 불일치 & 1형태소 & 석회 & 나는 석회 동굴에 간다. \\
\hline & & 2형태소 종성-단일자음 & 쌓고 & 나는 나무를 쌓고 불을 붙였다. \\
\hline & & 2형태소 종성-겹자음 & 앓고 & 나는 감기를 앓고 있다. \\
\hline \multirow[t]{8}{*}{ 경음화 } & 자소-음소 일치 & & 꼴찌 & 나는 달리기에서 꼴찌 했다. \\
\hline & 자소-음소 불일치 & 1형태소 & 꼭지 & 수도 꼭지 하나가 고장 났다. \\
\hline & & 2형태소 종성-단일자음 & 먹지 & 나는 밥을 먹지 않았다. \\
\hline & & 2형태소 종성-겹자음 & 밝지 & 내 동생 표정이 밝지 않다. \\
\hline & 자소-음소 일치 & & 토끼 & 나는 토끼 인형을 선물 받았다. \\
\hline & 자소-음소 불일치 & 1형태소 & 악기 & 나는 악기를 연주한다. \\
\hline & & 2형태소 종성-단일자음 & 받기 & 나는 상을 받기 위해 노력했다. \\
\hline & & 2형태소 종성-겹자음 & 밟기 & 나는 땅을 밟기 시작했다. \\
\hline \multirow[t]{8}{*}{ 연음화 } & 자소-음소 일치 & & 과거 & 나는 지나간 과거 경험을 잊었다. \\
\hline & 자소-음소 불일치 & 1형태소 & 국어 & 나는 국어 선생님이 제일 좋다. \\
\hline & & 2형태소 종성-단일자음 & 익어 & 사과가 빨갛게 익어 간다. \\
\hline & & 2형태소 종성-겹자음 & 늙어 & 할머니가 많이 늙어 보인다. \\
\hline & 자소-음소 일치 & & 이름 & 동생은 이름 쓰기를 어려워한다. \\
\hline & 자소-음소 불일치 & 1형태소 & 발음 & 나는 영어 발음 지도를 받았다. \\
\hline & & 2형태소 종성-단일자음 & 울음 & 나는 아기 울음 소리를 들었다. \\
\hline & & 2형태소 종성-겹자음 & 실음 & 공부하기 싫음 하지 말아라. \\
\hline \multirow[t]{8}{*}{ 비음화 } & 자소-음소 일치 & & 망고 & 나는 망고 하나를 샀다. \\
\hline & 자소-음소 불일치 & 1형태소 & 막내 & 막내 동생은 다섯 살이다. \\
\hline & & 2형태소 종성-단일자음 & 막는 & 길을 막는 것은 위험하다. \\
\hline & & 2형태소 종성-겹자음 & 깎는 & 연필 깎는 기계 주세요. \\
\hline & 자소-음소 일치 & & 잉크 & 파랑 잉크 주세요. \\
\hline & 자소-음소 불일치 & 1형태소 & 식물 & 나는 식물 이름을 많이 안다. \\
\hline & & 2형태소 종성-단일자음 & 식는 & 나는 국이 식는 줄 몰랐다. \\
\hline & & 2형태소 종성-겹자음 & 읽는 & 나는 책 읽는 것을 좋아한다. \\
\hline
\end{tabular}

Appendix 2. 오류유형별 조작적 정의와 오류의 예

\begin{tabular}{|c|c|c|c|}
\hline \multirow{2}{*}{ 조작적 정의 } & & \multicolumn{2}{|c|}{ 오류의 예 } \\
\hline & & 규칙단어 & 음운변동 단어 \\
\hline \multirow[t]{2}{*}{ 음운처리오류 } & 소리가 다른 자소로 잘못 표기하여 실험단어가 무의미한 단어로 변환되는 경우 & 과거 $\rightarrow$ 가거 & 악기 $\rightarrow$ 아끼 \\
\hline & 소리가 다른 자소로 잘못 표기하여 실험단어가 다른 의미 단어로의 대치되는 경우 & 토끼 $\rightarrow$ 도끼 & 국어 $\rightarrow$ 구어 \\
\hline \multirow[t]{4}{*}{ 표기처리오류 } & 실험단어의 낱자를 동일하게 발음되는 다른 낱자로 대치(칠종성, $H / N$, 겹받침)하는 경우 & - & 막내 $\rightarrow$ 막네 \\
\hline & 실험단어의 전체를 소리대로 표기하는 경우 & - & 꼭지 $\rightarrow$ 꼭찌 \\
\hline & 실험단어의부분을 소리대로 표기하는 경우 & - & 특히 $\rightarrow$ 특키 \\
\hline & 실험단어의 낱자를 한글에 없는 글자로 표기 하는 경우 & 과거 $\rightarrow$ 그 거 & 식는 $\rightarrow$ 싷는 \\
\hline \multirow[t]{2}{*}{ 형태처리오류 } & $\begin{array}{l}\text { 어간과 어미의 경계를 구분하지 못하여, 단어의 발음에 영향을 받아 어간과 어미가 변형되는 형태로 } \\
\text { 단어를 표기하는 경우 }\end{array}$ & - & 읽지 $\rightarrow$ 읽찌 \\
\hline & 소리가 같으나 표기법이 다른 동음이의어를 혼동하여 표기하는 경우 & - & 익어 $\rightarrow$ 이거 \\
\hline
\end{tabular}




\section{국문초록}

\section{초등 저학년 언어학습장애 아동의 철자쓰기 특성}

\section{한송이 · 정경희}

용인대학교 재활복지대학원 언어치료학과

배경 및 목적: 본 연구는 초등 저학년 언어학습장애 아동과 일반아동의 철자유형과 음운규칙 유형에 따른 철자쓰기 수행능력의 차이 를 알아보고자 하였다 방법: 연구대상은 학년을 일치시킨 경기지역 내 초등학교 1-3학년에 재학 중인 언어학습장애 아동 10명, 일반아 동 10 명으로 총 20 명이었다. 연구도구는 네 가지 철자유형과 네 가지 음운규칙이 포함된 단어를 선정하여 받아쓰기를 실시하였다. 결 과: 첫째, 철자유형에 따라 언어학습장애 아동과 일반아동 간의 유의미한 차이가 나타났다. 또한 집단과 철자유형 간 상호작용이 유의 미하였다. 일반아동은 불규칙단어 중 한 개의 형태소로 구성된 단어보다 두 개의 형태소로 이루어진 단어에 대한 철자쓰기 수행력이 더 높았으나 언어학습장애 아동은 다른 패턴을 보여주었다. 둘째, 음운규칙에 따라 언어학습장애 아동과 일반아동의 철자 수행력은 유의미한 차이를 보였으나, 집단과 철자유형 간 상호작용효과는 나타나지는 않았다. 셋째, 두 집단 모두 음운처리오류가 가장 높았고, 표기처리오류, 형태처리오류 순으로 나타났다. 논의 및 결론: 본 연구결과를 통해 추후 언어학습장애 아동의 철자쓰기 지도 시 철자유 형 및 음운규칙 유형을 고려할 필요가 있다는 점을 알 수 있었다. 특히 철자유형에서 형태소 수에 따라 철자쓰기 결과가 서로 다른 패턴 을 보여 철자쓰기에 있어 형태소지식의 사용에 대해 고려가 필요하다는 점을 시사해준다.

핵심어: 학령기 아동, 언어학습장애, 철자쓰기, 철자유형, 음운규칙

본 논문은 제 1 저자의 석사학위논문을수정·보완하였음.

\section{참고문헌}

가경신(2006). 읽기 능력과 읽기 인지 변인과의 상관. 독서연구, 15, 243-269.

고선희(2014). ADHD 아동과 일반 아동의 철자 특성 비교. 학습장애연구, 11, 261-274.

권순옥(2004). CIRC 협력학습프로그램이 학습장애아의 읽기 및 쓰기 능력에 미치는 효과. 부산대학교 대학원 석사학위논문.

김광해(2003). 등급별 국어교육용 어휘. 서울: 박이정.

김보배, 양민화(2015). 일반아동과 철자부진아동의 철자전략 비교: 음소의 조음정보를 중심으로. 언어청각장애연구, 20, 400-412.

김순호, 정경희(2015). 초등 저학년 읽기학습부진아동의 형태소인식과 읽기능력. 언어치료연구, 24, 35-47.

김애화(2009). 초등학교 학생의 철자특성 연구: 철자발달 패턴 및 오류 유형 분석. 초등교육연구, 22, 85-113.

김애화(2013). 초등학교 학생의 쓰기능력 예측변인에 관한 예비 연구. 언어청각장애연구, 18, 66-75.

김애화, 최한나, 김주현(2010). 초등학교 철자부진학생과 일반학생의 철자특성 비교 연구. 특수교육학연구, 45, 203-223.

김영욱(2012). 인공와우이식아동의 철자특성. 특수교육학연구, 47, 1-17.

김영욱, 김지숙, 김선영, 이윤선, 이현정(2013). 청각장애 초등학생의 철자쓰기 특성 분석. 특수교육, 12, 43-60.

김영태, 홍경훈, 김경희, 장혜성, 이주연(2009). 수용·표현어휘력검사(REVT). 서울: 서울장애인종합복지관.

김용욱(2015). 읽기장애학생과 일반학생의 단어인지와 철자법 특성 비교. 특수교육저널: 이론과 실제, 16, 363-386.

김은하, 정경희(2015). 초등 1-3학년 다문화가정 아동의 형태소인식능력. 언어청각장애연구, 20, 319-330.

김주영(2016). 하위유형별 언어학습장애 아동의 읽기 관련 요인 특성. 학습자중심교과교육연구, 16, 339-353.

배소영, 김미배, 윤효진, 장승민(2015). 한국어 읽기검사(KOLRA). 서울: 학지사.

송엽, 신가영, 배소영(2016). 초등학교 1, 2학년 언어.읽기부진아동과 정상아동의 해독 및 철자 특성. 언어치료연구, 25, 97-107.

양민화(2009). 유치원 아동의 철자발달 단기종단연구. 언어청각장애연구, 14, 14-33. 
양민화(2014). 음운론적 유형과 철자유형의 초기 철자발달. 언어청각장애연구, 19, 120-131.

이경님, 정민화(2002). 발음열 자동 생성기를 이용한 한국어 음운변화 형상의 통계적 분석. 한국음향학회지, 21, 656-664.

이창근(2007). 초등학교 문법 교육의 접근 원리. 국어교육연구, 41, 127-148.

정경희(2014). 1-3학년 학령기 아동의 형태소인식과 읽기능력. 언어청각장애연구, 19, 21-30.

정부자(2015). 초등 1-4학년 아동의 철자인식 발달특성과 관련 요인. 언어치료연구, 24, 63-71.

정현조, 김화수(2012). 읽기장애 아동의 효과적인 읽기 이해 전략에 대한 비교 연구. 발달장애연구, 16,45-73.

조희숙, 김선옥, 정정희(2006). 유아의 음운인식과 읽기가 쓰기능력에 미치는 영향: 단기 종단적 접근. 유아교육연구, 26, 371-388.

최윤정, 김영태, 윤혜련, 성지은(2011). 낱말친숙도 및 음운규칙 적용 유무에 따른 학령기 읽기장애 아동의 받침철자 인식 및 쓰기 특성. 언어청각장애

연구, 16, 154-170.

허현숙, 곽경미, 이윤경(2011). 언어학습부진아동의 구어능력과 읽기.쓰기능력과의 관계. 언어청각장애연구, 16, 23-33. 